\title{
Fat grafts enriched with adipose-derived stem cells
}

\author{
Ki Yong Hong \\ Department of Plastic and \\ Reconstructive Surgery, Dongguk \\ University Ilsan Hospital, Goyang, \\ Korea
}

\begin{abstract}
Autologous fat grafts are widely used in soft-tissue augmentation and reconstruction. To reduce the unpredictability of fat grafts and to improve their long-term survival, cell-assisted lipotransfer (CAL) was introduced. In this alternative method, autologous fat is mixed and grafted with stromal vascular fraction cells or adipose-derived stem/stromal cells (ASCs). In regenerative medicine, ASCs exhibit excellent therapeutic potential and are also simple to harvest. Although the efficacy of CAL has been demonstrated in experimental and clinical research, studies on its safety in terms of oncologic risk have reported inconclusive results. In order to establish CAL as a viable stem cell therapeutic approach, it will be necessary to demonstrate its oncologic safety in basic and clinical studies. Doing so could transform the paradigm of clinical strategy and practice for the treatment of a wide variety of diseases.
\end{abstract}

Keywords: Adipose tissue / Adipose-derived mesenchymal stem cells / Transplants

\section{FAT GRAFTS}

\section{Adipose tissue}

Autologous fat grafts have been widely used in soft-tissue augmentation and reconstruction surgery. Despite their numerous advantages, including a simple harvest technique, low cost, and easy accessibility, the applicability of autologous fat grafts is limited by their unpredictable long-term outcomes associated with poor graft retention $[1,2]$. In recent decades, several advances have been made to overcome the low rate of graft survival, including various refinements of existing techniques, the development of nanofat to reduce the size of fat particles used for injection, and the standardization of protocols for fat harvesting and processing [3-5].

Adipose tissue is composed of at least two functionally distinct types of fat: white and brown [6]. The primary roles of

\footnotetext{
Correspondence: Ki Yong Hong

Department of Plastic and Reconstructive Surgery, Dongguk University Ilsan Hospital, 27 Dongguk-ro, Ilsandong-gu, Goyang 10326, Korea

E-mail: pskyhong@gmail.com

This work was supported by a National Research Foundation of Korea (NRF) grant funded by the Korean government (MSIT) (No. NRF-2019R1F1A1063050).

Received July 9, 2020 / Revised July 15, 2020 / Accepted July 22, 2020
}

white adipose tissue are energy storage and the release of hormones and adipokines that modulate whole-body metabolism [7]. Consequently, the majority of studies related to adipose tissue have focused on the treatment of obesity, which contributes to an increased risk of developing type 2 diabetes, cardiovascular disorders, and cancer [8]. Additionally, white tissue can act as a thermal insulator and protect other organs from mechanical damage [9]. However, for plastic surgeons, the physical properties of white adipose tissue, not its function, make autologous fat grafts a useful component of their surgical strategies.

\section{Fate of fat grafts}

Adipose tissue is composed of adipocytes, adipose-derived stem/stromal cells (ASCs) and various other cells, including endothelial, mural, immune, and neuronal cells [10]. In addition, adipose tissue is highly vascularized, as each adipocyte is surrounded by an extensive capillary network [11]. Thus, angiogenesis is closely related to the maintenance and remodeling of adipose tissue. A recent study investigating the fate of adipocytes and ASCs after non-vascularized fat grafts identified three zones (survival, regenerating, and necrotic) in grafts [12]. In the survival zone, which is less than $300 \mu \mathrm{m}$ thick, both adipocytes 
and ASCs can survive. In the regenerating zone, which varies in thickness depending on aspects of the microenvironment such as vascularity, adipocytes die and only ASCs survive. Grafted adipose tissue in this zone degenerates within the first week, and regenerates into mature adipocytes after 3 months [13]. However, in the necrotic zone, which is at the center of the graft, both adipocytes and ASCs eventually die and are absorbed, after which the zone is filled with fibrous tissue. According to this theory, rapid revascularization of the surrounding recipient tissue and expansion of the regenerating zone resulting from increased vascularity are crucial for ensuring the survival of non-vascularized fat grafts.

\section{ADIPOSE-DERIVED STEM CELLS}

ASCs are multipotent mesenchymal stem/stromal cells (MSCs) with potential to differentiate not only into mesodermal lineages [14], such as adipocytes, osteoblasts, chondrocytes, fibroblasts, and myocytes, but also into non-mesodermal cell types, such as neuronal cells [15], hepatocytes [16], endothelial cells [17,18], and cardiomyocytes [19]. In addition to their extensive differentiation potential, ASCs secrete high levels of growth factors, including epidermal growth factor (EGF), vascular endothelial growth factor (VEGF), basic fibroblast growth factor (bFGF), keratinocyte growth factor (KGF), platelet-derived growth factor (PDGF), hepatocyte growth factor (HGF), and transforming growth factor-beta (TGF- $\beta$ ) [20]. In addition to growth factors, ASCs release cytokines, including fms-related tyrosine kinase 3 (Flt-3) ligand, granulocyte-colony stimulating factor (G-CSF), granulocyte macrophage-colony stimulating factor (GM-CSF), macrophage-colony stimulating factor (M$\mathrm{CSF}$ ), and various interleukins [21].

\section{Stromal-vascular fraction}

Manual isolation of ASCs typically involves enzymatic digestion of adipose tissue using collagenase, followed by centrifugation to separate floating mature adipocytes from other cells in the pellet $[3,22]$. The isolated cells in the pellet, known as stromal vascular fraction (SVF) cells, are a heterogenous mixture of cells including ASCs, endothelial cells, pericytes, immune cells, and fibroblasts [23]. SVF cells are a primary culture from adipose tissue, and are designated as passage 0 ASCs. While bone marrow stem cells constitute less than $0.002 \%$ of stromal cells, it has been estimated that ASCs constitute up to $2 \%$ of SVF cells. This underscores the clinical value of adipose tissue as a valuable source of competent adult stem cells [24]. However, the composition ratio of ASCs within SVF cells could vary widely depending on factors including age, sex, clinical history, and the harvest site.

\section{Definition of ASCs}

ASCs were first reported by Zuk et al. in 2001 [25]. These cells have been described using a variety of terms, and were finally named as ASCs by the International Federation for Adipose Therapeutics and Science (IFATS) [26]. The IFATS and the International Society for Cellular Therapy published a joint statement to establish minimal definitions of SVF cells and ASCs (Table 1) [27]. According to this declaration, SVF cells and ASCs should have a viability of $>70 \%$ and $>90 \%$, respectively. SVF cells express the following marker profile: CD13, CD29, CD44, CD73, and CD90 positive ( $>40 \%)$, and CD34 positive $(>20 \%)$, but CD31 $(<20 \%)$ and CD45 negative $(<50 \%)$. ASCs should be positive for CD13, CD29, CD44, CD73, CD90, and CD105 (>80\%), but negative for CD31, CD45, and CD235a (<2\%). ASCs can be distinguished from bone-marrow-derived MSCs as they are CD36-positive and CD106-negative. Moreover, they are expected to be able to differentiate into adipogenic, osteogenic, and chondrogenic lineages (Fig. 1).

\section{Isolation of ASCs}

Although it is possible to sort ASCs by flow cytometry using immunophenotypic surface markers, the necessary antibodies and reagents are mostly approved for research use only. Thus, for clinical purposes, ASCs can be obtained from SVF cells by in vitro cultivation on cell culture plates. They accumulate as spindle-shaped cells that are grossly indistinguishable from fibroblasts. ASCs from passage 3-7 are usually used for clinical and experimental purposes.

SVF cells can be isolated from adipose tissue by enzymatic digestion or non-enzymatic (mechanical) disruption techniques. The most common isolation protocol consists of enzymatic digestion with collagenase, centrifugation, and red blood cell lysis. In addition to collagenase, trypsin or dispase can be used to digest adipose tissue [27]. The enzymatic method currently

Table 1. Immunophenotypic surface markers of SVF cells and ASCs

\begin{tabular}{lccc}
\hline & SVF cells & ASCs & MSCs \\
\hline CD34 & + & \pm & - \\
CD45 & + & - & - \\
CD13 & \pm & ++ & ++ \\
CD73 & \pm & ++ & ++ \\
CD90 & \pm & ++ & ++ \\
CD105 & \pm & ++ & ++ \\
CD10 & & ++ & \pm \\
CD36 & & + & - \\
CD106 & & \pm & + \\
\hline
\end{tabular}

,$++ \geq 70 \% ;+, \geq 30 \%-70 \% ; \pm, \geq 2 \%-30 \% ;-, \leq 2 \%$.

SVF, stromal vascular fraction; ASCs, adipose-derived stem/stromal cells; MSCs, mesenchymal stem/stromal cells. 
Adipose tissue
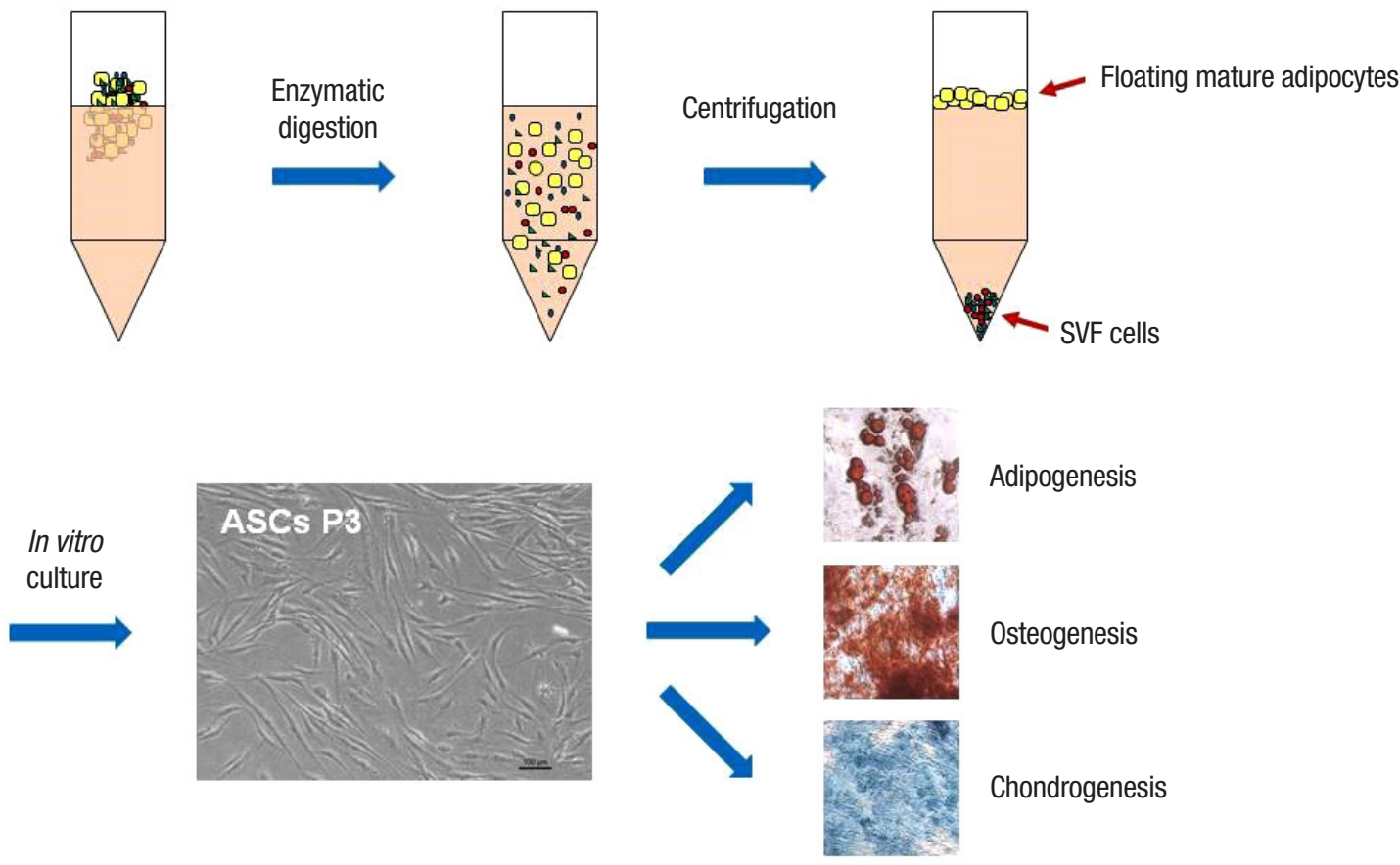

Fig. 1. The isolation procedure, morphology, and differentiation potential of adipose-derived stem/stromal cells (ASCs). Stromal vascular fraction (SVF) cells can be isolated by enzymatic digestion of adipose tissue using collagenase, followed by centrifugation to separate floating mature adipocytes from other cells. The isolated cells in the pellet, known as SVF cells, consist of a mixture of heterogeneous cell types including ASCs. ASCs can be obtained from the SVF cells by in vitro cultivation on cell culture plates. They accumulate as cells with a spindle-shaped morphology and the capacity to differentiate into adipogenic, osteogenic, and chondrogenic lineages. Their differentiation potential can be analyzed by histologic staining using Oil Red O for adipogenic differentiation, Alizarin Red for osteogenic differentiation, and Alcian Blue for chondrogenic differentiation.

yields more nucleated cells than the non-enzymatic method, indicating better efficiency in terms of isolation of ASCs. However, this protocol involves the use of xenogeneic components, especially collagenase, and these substances may pose potential risks and safety issues, such as exposure to infectious agents and immune reactions, although residual collagenase itself does not exhibit toxicity [28,29].

As an alternative approach, non-enzymatic methods that use physical force to separate ASCs within the adipose tissue have received increasing attention because they are simple, rapid, and inexpensive. Non-enzymatic disruption involves a combination of the following methods: filtration, centrifugation, red blood cell lysis, mechanical agitation, vortexing, vibration, and ultrasonic cavitation [20]. However, in comparison with enzymatic digestion, the disruptive physical forces employed in the non-enzymatic method are not sufficient to ensure that ASCs are released from the perivascular space, which is assumed to be a niche of ASCs, leading to a low yield of SVF cells. This is a critical disadvantage of this method [30].

\section{CELL-ASSISTED LIPOTRANSFER}

\section{Clinical efficacy}

Cell-assisted lipotransfer (CAL) has been reported to improve the clinical outcomes of fat grafts [31-33]. In this novel concept, a fat graft is enriched through the intermixture of autologous SVF cells. CAL involves increasing the density of ASCs in the adipose tissue by supplementing the tissue with SVF cells or ASCs (Fig. 2). As a result, ASC-poor aspirated fat can be converted into ASC-rich fat for grafting. The clinical efficiency of CAL was first demonstrated in a randomized controlled study in 2013 [34]. In the study, two fat types (30 mL each), enriched with ASCs $\left(2.0 \times 10^{7}\right.$ cells per $\mathrm{mL}$ of fat) or without ASCs, were injected into the subcutaneous plane as a bolus in the posterior part of the right and left upper arm. Magnetic resonance imaging measurements of the volume of the fat grafts at 4 months postoperatively revealed that the ASC-enriched fat grafts had significantly higher residual volumes than the control fat grafts $\left(23.0 \mathrm{~cm}^{3}\right.$ vs. $\left.4.7 \mathrm{~cm}^{3}\right)$. Despite several criticisms concerning the exceedingly high cell numbers, bolus injection, and the use of cultured ASCs, CAL has been accepted and studied as a cellular 


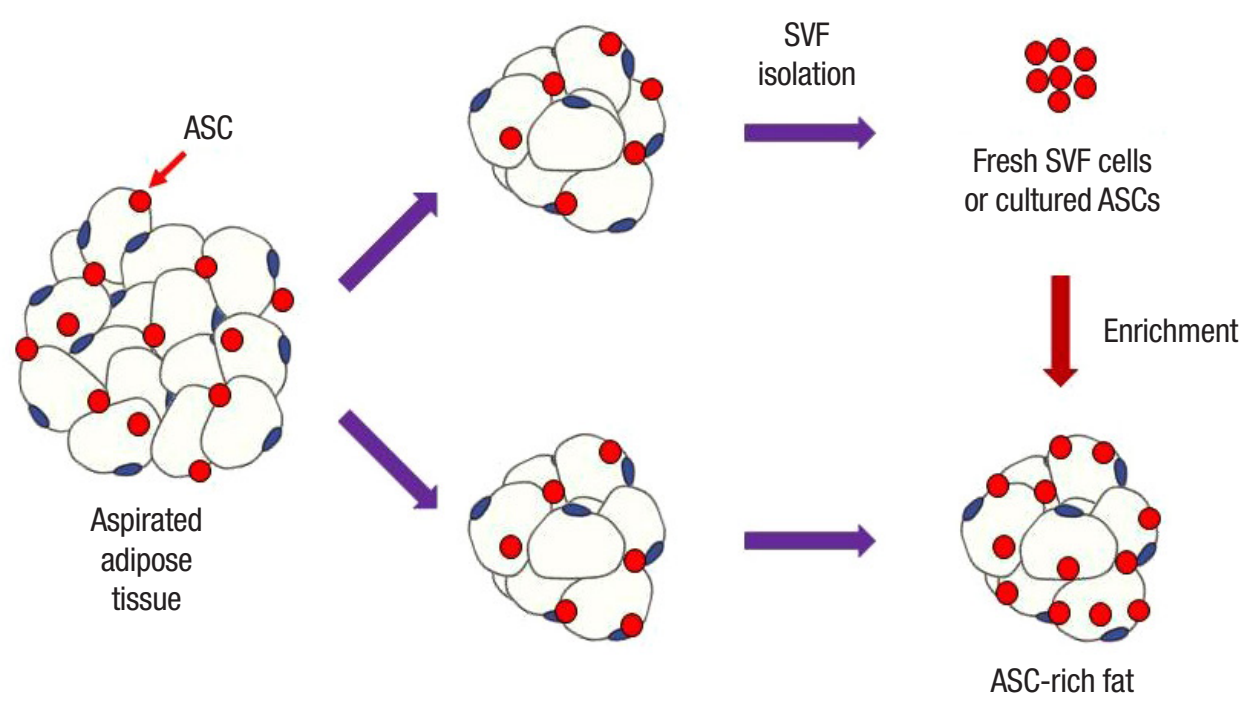

Fig. 2. Schematic illustration of cell-assisted lipotransfer (CAL). Stromal vascular fraction (SVF) cells are isolated using remnant fat other than the amount of fat planned for grafting. In CAL using adipose-derived stem/stromal cells (ASCs), two liposuction procedures are usually required, for ASC culture and fat grafting, respectively. Prior to grafting, the fat is enriched by mixing it with SVF cells or ASCs.

therapy for aesthetic and reconstructive applications. In another study, superior fat graft retention was observed when cultured ASCs were used as a source of cellular enrichment in CAL, instead of SVF cells [35].

Since the introduction of CAL, clinical trials targeting various sites in the body have been reported. The clinical trials of facial fat grafts enriched with SVF cells or ASCs are summarized in Table 2 [33,36-44]. CAL has been applied not only to treat lipodystrophic diseases, such as hemifacial atrophy (Parry-Romberg syndrome) and craniofacial microsomia, but also to perform cosmetic procedures, such as facial contouring and scar revision, and as an adjunct in face lift procedures. A recent meta-analysis suggested that CAL may be more applicable on the face than on the breast [45]. To verify this result, a prospective randomized controlled study investigating the efficacy of CAL in the craniofacial region is required.

\section{Mechanism}

Several mechanisms have been proposed to explain the enhancement of fat graft survival mediated by SVF cells or ASCs. According to one hypothesis, ASCs promote angiogenesis and subsequent revascularization by secreting various growth factors $[46,47]$. The second hypothesis states that ASCs can induce angiogenesis and adipogenesis by differentiating into endothelial cells and adipocytes [48]. To elucidate the fate and microenvironmental changes of fat, ASCs, and recipient tissue associated with CAL, the author generated an experimental animal model using two different transgenic reporter mice, and grafted both fat and ASCs expressing different fluorescent signals into wild-type mice [1]. Tracing analyses revealed that the donor ASCs participated in angiogenesis by differentiating into endothelial cells. Further, newly differentiated fat from donor ASCs and recipient tissue was found to be integrated with the donor fat, leading to improved graft retention. Moreover, ASC supplementation promoted angiogenesis and adipogenesis in a dosedependent manner. However, in a subsequent experimental study, intravenously injected ASCs concurrent with fat grafts were found to induce angiogenesis and adipogenesis by paracrine action, rather than by direct differentiation, although consistent results were found in terms of enhancing the survival of grafted fat [49].

\section{Safety}

The potential of ASCs to create a favorable microenvironment for improved graft retention and regeneration could also induce favorable conditions for tumor cell growth. In particular, the possibility cannot be ruled out that ASCs may stimulate dormant breast cancer cells after CAL in patients with a mild deformity after mastectomy for breast malignancy. To date, several studies, including in vitro and in vivo experiments, have investigated this issue and reported markedly controversial findings [50-53]. A clinical analysis of a large series of autologous fat grafts without supplementation with ASCs for breast reconstruction demonstrated a low complication rate and no evidence of increased oncologic risk [54-57]. The RESTORE-2 trial, which was the first prospective clinical trial of CAL for reconstruction after breast conservation therapy showed no increase in the local recurrence rate in 67 patients [58]. However, 
Table 2. Characteristics of clinical trials of facial fat grafts enriched with SVF cells and ASCs

\begin{tabular}{|c|c|c|c|c|c|c|c|c|c|}
\hline Study (year) & $\begin{array}{l}\text { Enriched } \\
\text { cells }\end{array}$ & $\begin{array}{l}\text { No. of } \\
\text { patients }\end{array}$ & Age (yr) & No. of operations & $\begin{array}{l}\text { Injected volume } \\
(\mathrm{mL})\end{array}$ & $\begin{array}{c}\text { Volumetric } \\
\text { measurement method }\end{array}$ & $\begin{array}{l}\text { Volume gain } \\
\text { (mL) }\end{array}$ & $\begin{array}{l}\text { Fat survival } \\
\text { rate (\%) }\end{array}$ & $\begin{array}{l}\text { Follow-up } \\
\text { period (mo) }\end{array}$ \\
\hline Sasaki (2015) [44] & SVF & 9 & $65.5(52-77)$ & 1 & $9.0 \pm 2.0$ & 3D scan & NA & $72.9 \pm 50.0$ & 12 \\
\hline Gentile et al. (2014) [43] & SVF & 10 & $23-67$ & 2 in $40 \%$ & NA & MRI, US & NA & $63^{\text {a) }}$ & 12 \\
\hline Chang et al. (2013) [42] & SVF & 10 & $27.5(19-35)$ & 2 in $30 \%, 3$ in $20 \%$ & $34.4 \pm 13.7$ & CT & NA & $68.3 \pm 1.7$ & 6 \\
\hline Li et al. (2013) [41] & SVF & 26 & $29.5 \pm 6.8$ & 1 & $17.5 \pm 7.3$ & CT & $11.5 \pm 5.3$ & $64.8 \pm 10.2$ & 6 \\
\hline Tanikawa et al. (2013) [40] & SVF & 7 & $12.1 \pm 2.2$ & 1 & $27 \pm 7$ & 3D CT & NA & $88.0 \pm 13.0$ & 6 \\
\hline Lee et al. (2012) [39] & SVF & 9 & $43.3 \pm 14.7$ & 1 & NA & Photography & NA & NA & 3 \\
\hline Koh et al. (2012) [38] & ASC & 5 & $28^{\text {a) }}$ & 1 & $29.9 \pm 6.7$ & 3D CT, 3D scan & $18.1 \pm 5.2$ & $61.1 \pm 13.7$ & 15 \\
\hline Sterodimas et al. (2011) [37] & SVF & 10 & $43.9 \pm 17.0$ & 1 & $74.3 \pm 47.0$ & Subjective satisfaction & NA & NA & 18 \\
\hline Tiryaki et al. (2011) [36] & SVF & 5 & NA & 1 & $29.2 \pm 16.2$ & Photography & NA & NA & 10 \\
\hline Yoshimura et al. (2008) [33] & SVF & 3 & $38.7 \pm 8.1$ & 1 & $100 \pm 10$ & Photography & NA & NA & 10.3 \\
\hline
\end{tabular}

Values are presented as mean (range) or mean $\pm \mathrm{SD}$.

SVF, stromal vascular fraction; ASCs, adipose-derived stem/stromal cells; NA, not available; 3D, three-dimensional; MRI, magnetic resonance imaging; US, ultrasound; CT, computed tomography.

${ }^{\text {alMean. }}$

the findings of 12-month follow-up after post-lumpectomy reconstruction remain inconclusive with regard to the oncologic safety of CAL in breast reconstruction. Thus, a prospective study with a longer follow-up period is needed to prove the oncologic safety of CAL for reconstruction after cancer treatment.

\section{PERSPECTIVE}

Autologous fat grafts are a primary choice of treatment for the reconstruction of mild to moderate contour deformities. ASCs have been noted for their simple harvesting procedure and excellent therapeutic potential in regenerative medicine. Nonetheless, several issues need to be elucidated regarding the use of fat grafts and CAL [59].

Clinicians need to know the optimal ratio of adipose tissue to SVF cells or ASCs for CAL. Moreover, it would be invaluable to develop precise surgical plans based on the predicted survival of fat grafts. Prior to answering practical questions, comparative analyses and standardization of fat harvest sites, techniques, and SVF isolation protocols with uniform parameters are necessary [2].

Demonstrating the oncologic safety of stem cell use with CAL is a prerequisite for harnessing its clinical potential. The safety of CAL is controversial due to the lack of experimental models capable of reproducing the complexity of the tumor microenvironment [60]. Therefore, suitable experimental models must be developed to identify potential mechanisms of oncologic risk. Ultimately, a prospective, multi-center case-cohort study based on a registry system will be crucial for providing convincing evidence.

Compared to SVF cells, the use of ASCs in Korea is limited due to legal and regulatory issues. The indications of cell therapy with ASCs are restricted to several diseases. Thus, clinical trials that provide convincing evidence regarding the efficacy and safety of ASCs are needed to obtain scientific, clinical, and legal authorization for their use.

A large number of ongoing studies and clinical trials will broaden the indications of ASC use and highlight the clinical value of ASCs beyond the field of plastic and reconstructive surgery. In the context of advances in fat grafts and CAL, ongoing research should expand to consider both the physical and functional properties of white adipose tissue.

\section{CONCLUSION}

Autologous fat grafts have emerged as a primary surgical option for soft-tissue augmentation and reconstruction. The use of fat grafts enriched with SVF cells or ASCs improves the long-term survival of grafts and shows promising results. If oncologic safety is demonstrated by scientific and clinical evidence, stem cell therapeutics such as CAL may shift the paradigm of clinical strategy and practice, with potential to be applied for various diseases.

\section{NOTES}

\section{Conflict of interest}

No potential conflict of interest relevant to this article was reported.

\section{ORCID}

Ki Yong Hong https://orcid.org/0000-0002-8579-0237 


\section{REFERENCES}

1. Hong KY, Yim S, Kim HJ, Jin US, Lim S, Eo S, et al. The fate of the adipose-derived stromal cells during angiogenesis and adipogenesis after cell-assisted lipotransfer. Plast Reconstr Surg 2018;141:365-75.

2. Strong AL, Cederna PS, Rubin JP, Coleman SR, Levi B. The current state of fat grafting: a review of harvesting, processing, and injection techniques. Plast Reconstr Surg 2015;136:897912.

3. Khouri RK Jr, Khouri RK. Current clinical applications of fat grafting. Plast Reconstr Surg 2017;140:466e-486e.

4. Tonnard P, Verpaele A, Peeters G, Hamdi M, Cornelissen M, Declercq H. Nanofat grafting: basic research and clinical applications. Plast Reconstr Surg 2013;132:1017-26.

5. Suszynski TM, Sieber DA, Van Beek AL, Cunningham BL. Characterization of adipose tissue for autologous fat grafting. Aesthet Surg J 2015;35:194-203.

6. Hassan M, Latif N, Yacoub M. Adipose tissue: friend or foe? Nat Rev Cardiol 2012;9:689-702.

7. Rosen ED, Spiegelman BM. Adipocytes as regulators of energy balance and glucose homeostasis. Nature 2006;444:847-53.

8. Adams KF, Schatzkin A, Harris TB, Kipnis V, Mouw T, BallardBarbash R, et al. Overweight, obesity, and mortality in a large prospective cohort of persons 50 to 71 years old. N Engl J Med 2006;355:763-78.

9. Trayhurn P. Adipocyte biology. Obes Rev 2007;8 Suppl 1:41-4.

10. Berry DC, Stenesen D, Zeve D, Graff JM. The developmental origins of adipose tissue. Development 2013;140:3939-49.

11. Rupnick MA, Panigrahy D, Zhang CY, Dallabrida SM, Lowell $\mathrm{BB}$, Langer R, et al. Adipose tissue mass can be regulated through the vasculature. Proc Natl Acad Sci U S A 2002;99: 10730-5

12. Eto H, Kato H, Suga H, Aoi N, Doi K, Kuno S, et al. The fate of adipocytes after nonvascularized fat grafting: evidence of early death and replacement of adipocytes. Plast Reconstr Surg 2012;129:1081-92.

13. Kato H, Mineda K, Eto H, Doi K, Kuno S, Kinoshita K, et al. Degeneration, regeneration, and cicatrization after fat grafting: dynamic total tissue remodeling during the first 3 months. Plast Reconstr Surg 2014;133:303e-313e.

14. Schaffler A, Buchler C. Concise review: adipose tissue-derived stromal cells: basic and clinical implications for novel cellbased therapies. Stem Cells 2007;25:818-27.

15. Ashjian PH, Elbarbary AS, Edmonds B, DeUgarte D, Zhu M, Zuk PA, et al. In vitro differentiation of human processed lipoaspirate cells into early neural progenitors. Plast Reconstr Surg 2003;111:1922-31.
16. Seo MJ, Suh SY, Bae YC, Jung JS. Differentiation of human adipose stromal cells into hepatic lineage in vitro and in vivo. Biochem Biophys Res Commun 2005;328:258-64.

17. Miranville A, Heeschen C, Sengenes C, Curat CA, Busse R, Bouloumie A. Improvement of postnatal neovascularization by human adipose tissue-derived stem cells. Circulation 2004; 110:349-55.

18. Planat-Benard V, Silvestre JS, Cousin B, Andre M, Nibbelink M, Tamarat R, et al. Plasticity of human adipose lineage cells toward endothelial cells: physiological and therapeutic perspectives. Circulation 2004;109:656-63.

19. Planat-Benard V, Menard C, Andre M, Puceat M, Perez A, Garcia-Verdugo JM, et al. Spontaneous cardiomyocyte differentiation from adipose tissue stroma cells. Circ Res 2004;94: 223-9.

20. Oberbauer E, Steffenhagen C, Wurzer C, Gabriel C, Redl H, Wolbank S. Enzymatic and non-enzymatic isolation systems for adipose tissue-derived cells: current state of the art. Cell Regen 2015;4:7.

21. Kilroy GE, Foster SJ, Wu X, Ruiz J, Sherwood S, Heifetz A, et al. Cytokine profile of human adipose-derived stem cells: expression of angiogenic, hematopoietic, and pro-inflammatory factors. J Cell Physiol 2007;212:702-9.

22. Lim MH, Ong WK, Sugii S. The current landscape of adiposederived stem cells in clinical applications. Expert Rev Mol Med 2014;16:e8.

23. Minteer DM, Marra KG, Rubin JP. Adipose stem cells: biology, safety, regulation, and regenerative potential. Clin Plast Surg 2015;42:169-79.

24. Strem BM, Hedrick MH. The growing importance of fat in regenerative medicine. Trends Biotechnol 2005;23:64-6.

25. Zuk PA, Zhu M, Mizuno H, Huang J, Futrell JW, Katz AJ, et al. Multilineage cells from human adipose tissue: implications for cell-based therapies. Tissue Eng 2001;7:211-28.

26. Gimble JM, Katz AJ, Bunnell BA. Adipose-derived stem cells for regenerative medicine. Circ Res 2007;100:1249-60.

27. Bourin P, Bunnell BA, Casteilla L, Dominici M, Katz AJ, March $\mathrm{KL}$, et al. Stromal cells from the adipose tissue-derived stromal vascular fraction and culture expanded adipose tissue-derived stromal/stem cells: a joint statement of the International Federation for Adipose Therapeutics and Science (IFATS) and the International Society for Cellular Therapy (ISCT). Cytotherapy 2013;15:641-8.

28. Chang H, Do BR, Che JH, Kang BC, Kim JH, Kwon E, et al. Safety of adipose-derived stem cells and collagenase in fat tissue preparation. Aesthetic Plast Surg 2013;37:802-8.

29. Conde-Green A, Kotamarti VS, Sherman LS, Keith JD, Lee ES, Granick MS, et al. Shift toward mechanical isolation of adi- 
pose-derived stromal vascular fraction: review of upcoming techniques. Plast Reconstr Surg Glob Open 2016;4:e1017.

30. Senesi L, De Francesco F, Farinelli L, Manzotti S, Gagliardi G, Papalia GF, et al. Mechanical and enzymatic procedures to isolate the stromal vascular fraction from adipose tissue: preliminary results. Front Cell Dev Biol 2019;7:88.

31. Matsumoto D, Sato K, Gonda K, Takaki Y, Shigeura T, Sato T, et al. Cell-assisted lipotransfer: supportive use of human adipose-derived cells for soft tissue augmentation with lipoinjection. Tissue Eng 2006;12:3375-82.

32. Yoshimura K, Sato K, Aoi N, Kurita M, Hirohi T, Harii K. Cellassisted lipotransfer for cosmetic breast augmentation: supportive use of adipose-derived stem/stromal cells. Aesthetic Plast Surg 2008;32:48-57.

33. Yoshimura K, Sato K, Aoi N, Kurita M, Inoue K, Suga H, et al. Cell-assisted lipotransfer for facial lipoatrophy: efficacy of clinical use of adipose-derived stem cells. Dermatol Surg 2008;34: 1178-85.

34. Kolle SF, Fischer-Nielsen A, Mathiasen AB, Elberg JJ, Oliveri RS, Glovinski PV, et al. Enrichment of autologous fat grafts with ex-vivo expanded adipose tissue-derived stem cells for graft survival: a randomised placebo-controlled trial. Lancet 2013;382:1113-20.

35. Zielins ER, Brett EA, Blackshear CP, Flacco J, Ransom RC, Longaker MT, et al. Purified adipose-derived stromal cells provide superior fat graft retention compared with unenriched stromal vascular fraction. Plast Reconstr Surg 2017;139:911-4.

36. Tiryaki T, Findikli N, Tiryaki D. Staged stem cell-enriched tissue (SET) injections for soft tissue augmentation in hostile recipient areas: a preliminary report. Aesthetic Plast Surg 2011; 35:965-71.

37. Sterodimas A, de Faria J, Nicaretta B, Boriani F. Autologous fat transplantation versus adipose-derived stem cell-enriched lipografts: a study. Aesthet Surg J 2011;31:682-93.

38. Koh KS, Oh TS, Kim H, Chung IW, Lee KW, Lee HB, et al. Clinical application of human adipose tissue-derived mesenchymal stem cells in progressive hemifacial atrophy (ParryRomberg disease) with microfat grafting techniques using 3-dimensional computed tomography and 3-dimensional camera. Ann Plast Surg 2012;69:331-7.

39. Lee SK, Kim DW, Dhong ES, Park SH, Yoon ES. Facial soft tissue augmentation using autologous fat mixed with stromal vascular fraction. Arch Plast Surg 2012;39:534-9.

40. Tanikawa DY, Aguena M, Bueno DF, Passos-Bueno MR, Alonso N. Fat grafts supplemented with adipose-derived stromal cells in the rehabilitation of patients with craniofacial microsomia. Plast Reconstr Surg 2013;132:141-52.

41. Li J, Gao J, Cha P, Chang Q, Liao Y, Liu C, et al. Supplementing fat grafts with adipose stromal cells for cosmetic facial contouring. Dermatol Surg 2013;39(3 Pt 1):449-56.

42. Chang Q, Li J, Dong Z, Liu L, Lu F. Quantitative volumetric analysis of progressive hemifacial atrophy corrected using stromal vascular fraction-supplemented autologous fat grafts. Dermatol Surg 2013;39:1465-73.

43. Gentile P, De Angelis B, Pasin M, Cervelli G, Curcio CB, Floris $\mathrm{M}$, et al. Adipose-derived stromal vascular fraction cells and platelet-rich plasma: basic and clinical evaluation for cell-based therapies in patients with scars on the face. J Craniofac Surg 2014;25:267-72.

44. Sasaki GH. The safety and efficacy of cell-assisted fat grafting to traditional fat grafting in the anterior mid-face: an indirect assessment by 3D imaging. Aesthetic Plast Surg 2015;39:83346.

45. Zhou Y, Wang J, Li H, Liang X, Bae J, Huang X, et al. Efficacy and safety of cell-assisted lipotransfer: a systematic review and meta-analysis. Plast Reconstr Surg 2016;137:44e-57e.

46. Zhu M, Dong Z, Gao J, Liao Y, Xue J, Yuan Y, et al. Adipocyte regeneration after free fat transplantation: promotion by stromal vascular fraction cells. Cell Transplant 2015;24:49-62.

47. Garza RM, Rennert RC, Paik KJ, Atashroo D, Chung MT, Duscher D, et al. Studies in fat grafting: Part IV. Adipose-derived stromal cell gene expression in cell-assisted lipotransfer. Plast Reconstr Surg 2015;135:1045-55.

48. Fu S, Luan J, Xin M, Wang Q, Xiao R, Gao Y. Fate of adiposederived stromal vascular fraction cells after co-implantation with fat grafts: evidence of cell survival and differentiation in ischemic adipose tissue. Plast Reconstr Surg 2013;132:363-73.

49. Hong KY, Kim IK, Park SO, Jin US, Chang H. Systemic administration of adipose-derived stromal cells concurrent with fat grafting. Plast Reconstr Surg 2019;143:973e-982e.

50. Orbay H, Hinchcliff KM, Charvet HJ, Sahar DE. Fat graft safety after oncologic surgery: addressing the contradiction between in vitro and clinical studies. Plast Reconstr Surg 2018; 142:1489-99.

51. Gebremeskel S, Gencarelli J, Gareau AJ, Levatte T, Dugandzic A, Johnston B, et al. Promotion of primary murine breast cancer growth and metastasis by adipose-derived stem cells is reduced in the presence of autologous fat graft. Plast Reconstr Surg 2019;143:137-47.

52. Teufelsbauer M, Rath B, Moser D, Haslik W, Huk I, Hamilton G. Interaction of adipose-derived stromal cells with breast cancer cell lines. Plast Reconstr Surg 2019;144:207e-217e.

53. Silva MMA, Kokai LE, Donnenberg VS, Fine JL, Marra KG, Donnenberg $\mathrm{AD}$, et al. Oncologic safety of fat grafting for autologous breast reconstruction in an animal model of residual breast cancer. Plast Reconstr Surg 2019;143:103-12. 
54. Delay E, Garson S, Tousson G, Sinna R. Fat injection to the breast: technique, results, and indications based on 880 procedures over 10 years. Aesthet Surg J 2009;29:360-76.

55. Petit JY, Lohsiriwat V, Clough KB, Sarfati I, Ihrai T, Rietjens M, et al. The oncologic outcome and immediate surgical complications of lipofilling in breast cancer patients: a multicenter study: Milan-Paris-Lyon experience of 646 lipofilling procedures. Plast Reconstr Surg 2011;128:341-6.

56. Petit JY, Botteri E, Lohsiriwat V, Rietjens M, De Lorenzi F, Garusi $\mathrm{C}$, et al. Locoregional recurrence risk after lipofilling in breast cancer patients. Ann Oncol 2012;23:582-8.

57. Gale KL, Rakha EA, Ball G, Tan VK, McCulley SJ, Macmillan $\mathrm{RD}$. A case-controlled study of the oncologic safety of fat graft- ing. Plast Reconstr Surg 2015;135:1263-75.

58. Perez-Cano R, Vranckx JJ, Lasso JM, Calabrese C, Merck B, Milstein AM, et al. Prospective trial of adipose-derived regenerative cell (ADRC)-enriched fat grafting for partial mastectomy defects: the RESTORE-2 trial. Eur J Surg Oncol 2012;38: 382-9.

59. Bayram Y, Sezgic M, Karakol P, Bozkurt M, Filinte GT. The use of autologous fat grafts in breast surgery: a literature review. Arch Plast Surg 2019;46:498-510.

60. Casiraghi F, Remuzzi G, Abbate M, Perico N. Multipotent mesenchymal stromal cell therapy and risk of malignancies. Stem Cell Rev Rep 2013;9:65-79. 